\title{
天空輝度・放射輝度分布を推定する天空モデルの整備 ADJUSTMENT OF THE SKY MODEL FOR THE ESTIMATION OF LUMINANCE AND RADIANCE DISTRIBUTIONS OF SKY
}

\author{
井川憲男* \\ Norio IGAWA
}

\begin{abstract}
In the former paper, All Sky Model to estimate the sky luminance and the radiance distribution that authors had proposed on 2004 was improved, and the improved model was compared with former All Sky Model, CIE Standard General Sky and Perez model.

Afterward, further examinations are repeated, and appropriate coefficients for the basic equation were derived applying the same structure of the basic equation, which can estimate high accurate sky luminance and radiance distributions of with small regional dependency.

When the range of the combination of coefficients of the CIE Standard General Sky was considered too much, the limit turned out in the estimating accuracy by the model. Some ranges of the combination of coefficients were arranged a little, the re-improvement was tried, and the coefficients for more high accurate estimation were derived.
\end{abstract}

In this paper, All Sky Model adjusted again is introduced.

Keywords : Sky luminance distribution, Sky radiance distribution, All Sky Model, Adjustment 天空輝度分布, 天空放射輝度分布，All Sky Model, 整備

\section{1. はじめに}

既報 ${ }^{1}$ において、2004 年に筆者らが提案した天空輝度・放射輝度 分布を推定する All Sky Model-L、R（以下、As と略記） 2)を改良し たモデル（既報ではI-As と略記したが、本論文では I-As_O と略記） を、CIE 標準一般天空 (CIE Standard General Sky : Gs) ${ }^{3)}$ 、Perezの All Weather Model $(\mathrm{Aw})^{4}$ ) と比較検討した結果を報告した。

CIE 標準一般天空の 15 の Type について、Type の出現頻度の検討

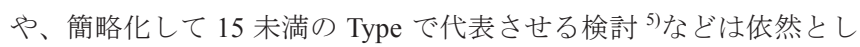
てみられるが、Type を決定する方法は確立されていない。天空輝度 分布の実測を継続している測定所が非常に少なこともあり、Type と 天空輝度分布の実測データとの比較検討も十分とはいえない。

その後、I-As_Oについて更なる検討を重ね、モデルの基本式の構 造は同様であるが、より推定精度が高く地域依存性の小さい適切な 係数を導出する。従前のモデル化においては、天空状態を示す係数 について、Gs の係数を考慮して、これらとあまり乘離しない範囲の 係数の組み合わせとなるように表していた。

また、既報で述べたように、Type は限定された狭い指標範囲に出 現するとは限らず、広範囲の指標の下に出現する Type もあるため、 Type を特定する手法の確立が困難となっている。

このような状況から、本研究は細分化された指標の範囲に出現す る天空輝度・放射輝度の平均的分布を連続的に表すことで害用的な モデルとして表現することを目指しているものである。なお、CIE 標準一般天空の係数の組み合わせを意識しすぎるとモデルの推定精
度に限界があることが判明したため、係数の組み合わせの範囲を僅 かに拡大して整備を試み、より推定精度の高い係数を導出する。

本論文は、整備された improved All Sky Model（i-As）の開発と検 証について報告する。

\section{2. モデル化と検証に使用する測定データ}

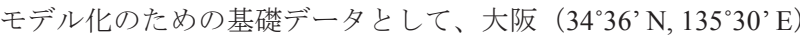
における 2007 年 1 月 1 日から 2008 年 12 月 31 日までの IDMP 注 1 のガイド ${ }^{6}$ に準じた測定データを使用する。

また、モデルの検証には、2006 年 1 月 1 日から 2011 年 12 月 31 日までの大阪における測定データを使用する。測定方法は既報に述

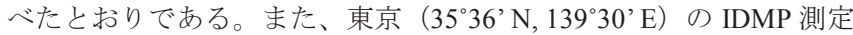
所7で取得した、1992 年 3 月 1 日から 1993 年 9 月 30 日までの天空 輝度分布と、1993 年 1 月から同年 9 月までの放射輝度分布のデータ を使用寸る。なお、東京においては、スカイスキャナー (MS-300LR： 英弘精機)を使用し、1992 年は輝度分布のみを対象として 1 回の 145 点の分布測定は約 2 分 30 秒であった。1993 年は輝度と放射輝度を 同時測定し測定時間は約 3 分 30 秒であった。大阪の 6 年間の天空輝 度・放射輝度分布はスカイスキャナー（MS-312LR：英弘精機）で 測定し、1 回の測定時間は約 4 分 30 秒であった。天空状態の急変を 考慮すると測定時間は可能な限り短いほうが好ましい。しかし、放 射輝度測定用センサーは時定数が大きいため、高速測定では時定数 に起因する誤差が大きくなる。大阪における輝度・放射輝度の測定

\footnotetext{
* 大阪市立大学大学院生活科学研究科 特任教授 $\cdot$ 博士 (工学) Prof., Graduate School of Human Life Science, Osaka City University, Dr. Eng.
} 
時間は東京に比べて長く、1 点ごとの放射輝度の測定値は安定する と思われるが、145 点を測定する時間が長くなるため、測定中の天 空状態の急変に十分に対応しているとは言い難い。センサーの特性 を把握した適当な測定時間の設定も重要な課題となる。現実的には 輝度分布のみを高速測定し、相対輝度分布を相対放射輝度分布に転 用する方が好ましいとも考えられる。なお、既報の検証で使用した イタリアの測定データは、詳細に吟味した結果、日射量の測定值が 不安定であることが判明し、本論文の検証には使用しない。

なお、実測データが次に示す状況の場合、当該時刻の全データを 削除し、モデル化や検証の対象としない。

(1) 天空輝度・天空放射輝度の 145 点の測定において、 1 個でも測 定值が 0 以下である場合。

（2）周辺建物付属物や未確認物体などにより、一時的に影が発生し たと考えられる場合。

（3） 日射量や照度の測定值に鳥（主にカラス）などの飛来による影 響があると考えられる場合。(なお、2011 年にはセンサー上空 に釣り糸を $30 \mathrm{~cm}$ 間隔に平行に張りこれを防いだ。)

（4）直達日射・直射照度の測定における太陽追尾や、天空日射量、 全天空照度の測定值に顕著な異常が見られる場合。

既報では、CIE 標準一般天空のどの Type とも相対 RMSE が 70\% 以上乘離する実測データを除外していた。今回は、前記(1)〜(4)に該 当しない全データを使用する。

なお、本研究における鉛直面照度・日射量は、測定地点特有のア ルベドの影響を除くため、地物反射を遮って地域依存性を極力小さ くするように配慮して測定を行っている。

\section{3. 天空状態を表す指標}

天空状態を表す指標として、Linke の混濁因子が 2.0 の場合を晴天 の代表とし、晴天指標 $(K c)$ と澄清指標 $(\mathrm{Cle})$ とを定義する。なお、既 報で示したCle が複雑すぎたため、式(4)のように改める。

$K c=E e g / S e e g$

$\mathrm{Cle}=(1-\mathrm{Ce}) /(1-\mathrm{Ces})$

Seeg $=0.84 \cdot E e o / m \cdot \exp (-0.054 \cdot m)$

Ces $=0.08302+0.5358 \cdot \exp \left(-17.394 \cdot \gamma_{s}\right)+0.3818 \cdot \exp \left(-3.2899 \cdot \gamma_{s}\right)(4)$ こで、Eeg: 水平面全天日射量 $\left[\mathrm{W} / \mathrm{m}^{2}\right] 、 S e e g$ : 基準全天日射量 $\left[\mathrm{W} / \mathrm{m}^{2}\right]$ 、 $C e$ : クラウドレイショ $(=E e d / E e g) 、 C e s:$ 基準クラウドレイショ、 $E e o$ : 大気外法線直達日射量 $\left[\mathrm{W} / \mathrm{m}^{2}\right] 、 m$ : 大気路程 ${ }^{8)} 、 \gamma_{\mathrm{s}}$ : 太陽高 度 $[\mathrm{deg}]$, Eed : 水平面天空日射量 $\left[\mathrm{W} / \mathrm{m}^{2}\right]$ 。

\section{All Sky Model の再改良}

基本式は、旧来の As の式 (Gs と同等) を継承し、この中の係数 $(a \sim e)$ を得る式を再度改良する。

整備された測定データから、まず、2007 年と 2008 年の測定值を 基に、天空指標とする $K c$ と Cle を算出する。次に、太陽高度帯を 5 度（ \pm 2.5 度）ごとに分割する。分割された太陽高度帯ごとに $K c 、$ Cleを $0.05( \pm 0.025)$ 間隔で細分し、それぞれの区域の平均天空輝度 分布を求める。得られた平均天空輝度分布を基に、回帰分析により 太陽と天空要素の角距離と天空要素の高度の関数として、Kc-Cle 区 域ごとの係数 $(a \sim e)$ を得る。

天空輝度分布と天空放射輝度分布の基本式の構成は、CIEの標準
一般天空と同様に、それぞれ、式(5)、式(6)で表される。

$\operatorname{Lva}\left(\gamma_{s}, \gamma, \zeta\right)=\operatorname{Lvz}\left(\gamma_{s}\right) \cdot \operatorname{Lv}\left(\gamma_{s}, \gamma, \zeta\right)=\operatorname{Lvz}\left(\gamma_{s}\right) \frac{\varphi(\gamma) \cdot f(\zeta)}{\varphi(\pi / 2) \cdot f\left(\pi / 2-\gamma_{s}\right)}$

$\operatorname{Lea}\left(\gamma_{s}, \gamma, \zeta\right)=\operatorname{Lez}\left(\gamma_{s}\right) \cdot \operatorname{Le}\left(\gamma_{s}, \gamma, \zeta\right)=\operatorname{Lez}\left(\gamma_{s}\right) \frac{\varphi(\gamma) \cdot f(\zeta)}{\varphi(\pi / 2) \cdot f\left(\pi / 2-\gamma_{s}\right)}$

$\varphi(\gamma)=1+a \cdot \exp (b / \sin \gamma)$

$f(\zeta)=1+c\{\exp (d \cdot \varsigma)-\exp (d \cdot \pi / 2)\}+e \cdot \cos ^{2} \zeta$

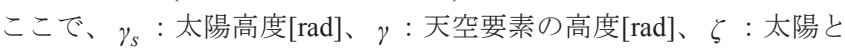
天空要素の角距離 $[\mathrm{rad}]$ 。

係数 $a \sim e$ は、式(9)の $x$ で、表1に示す係数 $A \sim H$ により得られる。

$$
x=A+B \cdot \exp \left(-\frac{G_{k c}}{2}\right)+E \cdot \exp \left(-\frac{G_{C l e}}{2}\right)+H \cdot \exp \left(-\frac{G_{K c}+G_{C l e}}{2}\right)
$$

$G_{K c}=\{(K c-C) / D\}^{2} 、 G_{C l e}=\{(C l e-F) / G\}^{2}$

以上により、日射量のデータを基に、相対天空輝度分布、相対天 空放射輝度分布を得ることができる。

天空分布を実際に活用寸るためには、天頂輝度、天頂放射輝度を 乗じて絶対值を得る必要がある。

全天日射量と天空日射量から相対天空輝度分布 $(L v)$ が得られると、 天頂輝度は、式(10)で表すことができる。

$\operatorname{Lvz}\left(\gamma_{s}, K c, C l e\right)=\frac{E v d}{\int_{\gamma=0}^{\pi / 2} \int_{\alpha=0}^{2 \pi} L v\left(\gamma_{s}, \gamma, \zeta\right) \cdot \cos \gamma \cdot d \gamma \cdot d \alpha}$

式(10)の分母の積分計算は、若干煩雑で計算時間を要する。計算 時間を短縮するため、式(11)、式(12)のように $L z E d を$ 相対天空分布の 積分值の逆数で表し、事前にこれを求める式を作成しておく。

$$
\begin{aligned}
& \operatorname{Lvz}\left(\gamma_{s}, K c, C l e\right)=E v d \cdot L z E d \\
& L e z\left(\gamma_{s}, K c, C l e\right)=E e d \cdot L z E d
\end{aligned}
$$

ここで、事前に太陽高度帯ごとに Kc-Cle 区域ごとに LzEdを計算し、 太陽高度帯ごとの計算結果をまとめると、式(13)のように太陽高度 と Kc と Cle の関数として表すことができる。

$$
\begin{aligned}
L z E d & =\sum_{k=0}^{5}\left[A(k) \cdot K c^{k}\right] \\
A(k) & =\sum_{j=0}^{6}\left[B(j, k) \cdot C l e^{j}\right], B(j, k)=\sum_{i=0}^{5}\left[C(i, j, k) \cdot \gamma_{s}^{i}\right]
\end{aligned}
$$

$L z E d$ を求めるための係数を表 2 に示す。ここで、太陽高度を $5^{\circ}$ から $90^{\circ}$ までの $5^{\circ}$ 間隔として、Kc と Cle をそれぞれ 0.1 に分割して、 表 2 を基に簡易に計算した $L z E d$ と、相対天空分布から方位角と高

\begin{tabular}{|c|c|c|c|c|c|}
\hline & $a$ & b & $c$ & $d$ & $e$ \\
\hline A & -1.0193 & -0.3646 & -3.3246 & -3.8472 & -0.6370 \\
\hline B & -0.0955 & 0.8806 & 1.8413 & 2.1573 & 0.5995 \\
\hline $\mathrm{C}$ & -0.0823 & 1.6503 & 0.8436 & -0.5050 & 1.0259 \\
\hline D & 0.4530 & 0.3319 & 0.3009 & 0.6257 & 1.3334 \\
\hline $\mathbf{E}$ & -0.1294 & -0.6525 & 8.3642 & 61.0275 & -0.0022 \\
\hline $\mathbf{F}$ & -0.2876 & -0.2681 & 0.8183 & -3.2725 & 1.0765 \\
\hline G & 0.3169 & 0.5434 & 0.5424 & 1.2096 & 0.7066 \\
\hline $\mathbf{H}$ & 6.4046 & -12.3328 & 9.1901 & 31.1039 & 0.5187 \\
\hline Note & & if $b>0, b=0$ & if $c<0, c=0$ & & if $e<0, e=0$ \\
\hline
\end{tabular}
度角を 2 間隔で数值積分して得た $L z E d$ との関係を図 1 に示すが、 $L z E d$ を使用して簡易に計算しても、相対天空分布の全天に渡る積分 と同等の值となり、実用的に十分な精度が得られことを示している。

表 1 係数表 
表 $2 L z E d$ を求めるための係数

\begin{tabular}{|c|c|c|c|c|c|c|c|}
\hline \multirow{2}{*}{$k$} & \multirow[b]{2}{*}{$j$} & \\
\hline & & 5 & 4 & 3 & 2 & 1 & 0 \\
\hline \multirow{7}{*}{5} & 6 & 5.6146 & -29.4046 & 47.2024 & $\begin{array}{l}-43.8510 \\
\end{array}$ & 8.2509 & -0.9358 \\
\hline & 5 & -17.9921 & 93.4316 & -142.8905 & 130.9200 & -17.7456 & 2.6364 \\
\hline & 4 & 20.0121 & \begin{tabular}{|l|l|}
-103.1918 \\
\end{tabular} & 142.9116 & -130.0067 & 3.1167 & -3.7005 \\
\hline & 3 & -12.0503 & 55.2228 & $\begin{array}{l}-58.2657 \\
\end{array}$ & 49.5379 & 14.3877 & 3.5037 \\
\hline & 2 & 8.2042 & -28.2605 & 23.5534 & -13.0987 & -9.0805 & -2.2572 \\
\hline & 1 & -2.2514 & 7.3074 & \begin{tabular}{|l|}
-5.7338 \\
\end{tabular} & 2.4593 & 2.3038 & 1.2745 \\
\hline & $\mathbf{0}$ & 0.4774 & -1.2853 & 0.8565 & -0.2806 & -0.1641 & -0.7447 \\
\hline \multirow{7}{*}{4} & 6 & -17.2129 & 85.8973 & -129.4606 & 125.4744 & -16.6675 & -1.7011 \\
\hline & 5 & 63.0588 & -298.9370 & \begin{tabular}{|l|l|}
420.7243 \\
\end{tabular} & -391.1156 & 25.7323 & 8.4401 \\
\hline & 4 & -86.5230 & 382.9478 & -477.7507 & 419.8383 & 28.0500 & -10.4232 \\
\hline & 3 & 64.5195 & -250.6187 & 249.3821 & -189.4251 & -70.2059 & 1.0365 \\
\hline & 2 & -36.9118 & 122.2518 & -103.4001 & 56.5677 & $\mathbf{3 8 . 5 4 3 7}$ & 4.9664 \\
\hline & 1 & 8.3944 & -26.3761 & 19.1065 & -8.7967 & -9.4755 & -3.6080 \\
\hline & 0 & -1.6652 & 4.5943 & -3.1165 & 1.4959 & 0.5221 & 1.9573 \\
\hline \multirow{7}{*}{3} & 6 & 21.5603 & -98.3234 & 133.2000 & \begin{tabular}{|l|}
-134.7364 \\
\end{tabular} & 5.7213 & 7.9890 \\
\hline & 5 & -88.8005 & 376.6700 & -473.6141 & 443.8715 & 15.9462 & -31.5361 \\
\hline & 4 & 140.5464 & -549.7882 & 617.7442 & -524.2791 & -92.1837 & 41.4865 \\
\hline & 3 & -115.2602 & \begin{tabular}{|l|l|}
40853 \\
\end{tabular} & -389.1329 & \begin{tabular}{|c|}
279.5759 \\
\end{tabular} & $\begin{array}{l}121.5988 \\
\end{array}$ & -18.9449 \\
\hline & 2 & $\mathbf{5 8 . 4 3 2 5}$ & -188.1080 & 158.1039 & -90.2370 & -60.4685 & -0.8295 \\
\hline & 1 & -12.5318 & 38.1286 & \begin{tabular}{|l|}
-26.3229 \\
\end{tabular} & 14.5404 & 13.3797 & 2.5300 \\
\hline & 0 & 1.7622 & -5.0850 & 2.9477 & -2.1838 & -0.5745 & -1.2611 \\
\hline \multirow{7}{*}{2} & 6 & -16.1603 & 62.0261 & $\begin{array}{l}-68.6303 \\
\end{array}$ & 66.7874 & 9.3995 & -8.0240 \\
\hline & 5 & 68.1074 & -249.5476 & 263.2480 & -233.4506 & -51.2836 & 30.4587 \\
\hline & 4 & -110.3658 & 384.7705 & -376.5734 & 301.1853 & 105.3289 & -41.6451 \\
\hline & 3 & 88.4298 & -291.6143 & 255.1865 & -180.4192 & -100.9524 & $\mathbf{2 4 . 4 2 7 4}$ \\
\hline & 2 & -39.1455 & 122.2380 & -95.2499 & 60.1343 & 43.8912 & -5.8629 \\
\hline & 1 & 8.5411 & -25.5973 & 17.1831 & -11.9369 & -7.4727 & 0.8271 \\
\hline & 0 & -0.5530 & 1.8213 & -0.3930 & 1.0051 & 0.2158 & -0.0791 \\
\hline \multirow{7}{*}{1} & 6 & 5.6538 & -18.5946 & 15.3888 & -15.0642 & -6.8261 & 2.4525 \\
\hline & 5 & -22.4881 & 72.5977 & -58.6626 & 54.7188 & 28.0338 & -9.9369 \\
\hline & 4 & 34.5496 & -109.0127 & 83.4590 & -75.1759 & -45.1168 & 15.8059 \\
\hline & 3 & -26.0768 & 80.1132 & -55.9029 & 49.8447 & $\mathbf{3 4 . 7 2 5 4}$ & -12.6379 \\
\hline & 2 & 10.1609 & -30.7499 & 19.0722 & -17.7449 & -11.9372 & 5.3456 \\
\hline & 1 & -1.4801 & 4.7414 & -1.9300 & 2.6996 & 1.2676 & -1.0207 \\
\hline & 0 & 0.0550 & -0.2373 & -0.0316 & -0.0642 & 0.0032 & -0.0227 \\
\hline \multirow{7}{*}{0} & 6 & -0.8791 & 3.2070 & -2.8856 & 3.0796 & 0.2823 & 0.1061 \\
\hline & 5 & 2.7495 & -10.1893 & 8.5197 & -10.6148 & -1.0694 & 0.2046 \\
\hline & 4 & -3.0179 & 11.6684 & -8.6199 & 14.0185 & 1.3755 & -1.7036 \\
\hline & 3 & 1.1932 & -5.4566 & 3.0029 & -8.7173 & -0.5736 & 2.7262 \\
\hline & 2 & -0.0024 & 0.7879 & -0.0560 & 2.4222 & -0.1517 & -1.4338 \\
\hline & 1 & 0.0089 & -0.1344 & 0.1890 & -0.1446 & 0.1348 & -0.1598 \\
\hline & 0 & -0.0018 & 0.0124 & -0.0062 & -0.0134 & -0.0078 & 0.4086 \\
\hline
\end{tabular}

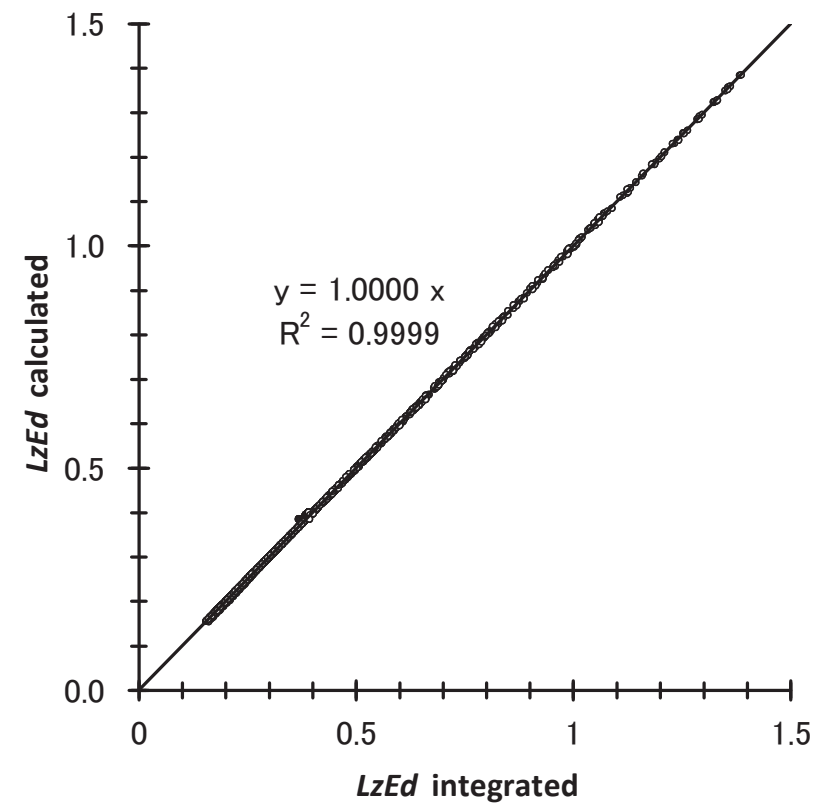

図 1 相対分布の全天を積分して得た $L z E d$ と簡易に計算した $L z E d$

\section{5. 天空輝度分布・放射輝度分布の推定精度の検証}

既報で比較対象とした、As とAw と I-As_O ならびに今回整備し た All Sky Model（i-As）の推定精度を、CIE の IDMP に準じて取得 した、2006 年 1 月から 2011 年 12 月までの大阪の測定データと、1992
年 3 月から 1993 年 9 月までの東京の測定データで比較する。

具体的には、全天日射量、天空日射量、全昼光照度、天空照度な どから推定した各モデルの值を、天空輝度分布と天空放射輝度分布 の実測值と比較する。

なお、既報 ${ }^{1)}$ では天頂輝度と天頂放射輝度に実測值を使用して各 天空要素の絶対值を推定した。しかし、一般的に天頂輝度・天頂放 射輝度のデータは入手できない。このため、日射量から天空の相対 分布を推定し、次いで相対分布と全天空照度・天空日射量から天頂 輝度・天頂放射輝度を推定し、これを相対分布に乗じて絶対值で示 寸分布を得る方が実用的である。本論文では次式で得られた天頂輝 度・天頂放射輝度を使用する注 2 。

$$
L v z=\frac{E v d}{\sum_{p=1}^{145} L v_{p} \cdot c_{p}} \quad \text { (14), } \quad \text { Lez }=\frac{E e d}{\sum_{p=1}^{145} L e_{p} \cdot c_{p}}
$$

ここで、 $p$ : スカイスキャナーによる 145 点の天空要素の測定点、 $L v_{p}$ : $p$ 点の相対天空輝度の推定値、 $L e_{p}: p$ 点の相対天空放射輝度の推定值、 c: 天空要素 $p$ の立体角投射率。

\section{1 天空分布推定值の年間の RMSE と MBE の平均値の比較}

東京と大阪における天空輝度分布と天空放射輝度分布の実測值と 各モデルによる推定值の RMSE と MBE の年平均值を表 3 と表 4 に示す。図 $2 、 3$ に天空輝度分布の、図 $4 、 5$ に天空放射輝度分布の 年別の RMSE と MBE の比較を示す。

天空輝度分布と天空放射輝度分布の推定精度の傾向は非常に似通 った特性を示しており、いずれのモデルもかなり良い推定精度を有 していると評価できる。As の RMSE は東京においては I-As_O より 小さいが、大阪ではI-As_O の方が小さく、モデルを作成したデータ に依存する傾向が若干みられる。天空輝度分布については $i$-As の RMSE がいずれの年でも他に比べて最も小さい。

天空放射輝度分布については、 $i$-As の RMSE が他に比べて小さく、 最も推定精度が優れている。As の RMSE は東京では $i$-As に次いで 小さいが、全年を通すとAs、Aw、I-As_Oの相違は大きくない。

今回比較対象としたモデルはいずれもかなり高精度なモデルであ ることが確認できるが、整備して提案する $i$-As は、す心゙ての条件に おいて年間平均の RMSE と MB の值が最も小さく、より高精度なモ デルであることが確認できる。

表 3 天空輝度分布の推定精度の比較（東京、大阪）

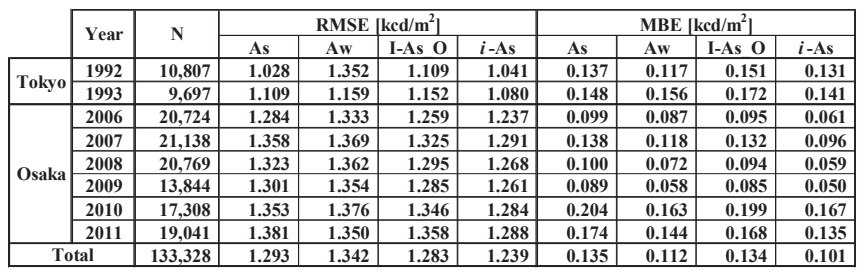

表 4 天空放射輝度分布の推定精度の比較（東京、大阪）

\begin{tabular}{|c|c|c|c|c|c|c|c|c|c|c|}
\hline & \multirow{2}{*}{ Year } & \multirow{2}{*}{$\mathbf{N}$} & \multicolumn{4}{|c|}{ RMSE $\left[\mathrm{W} / \mathrm{m}^{2} / \mathrm{sr}\right]$} & \multicolumn{4}{|c|}{ MBE $\left[\mathrm{W} / \mathrm{m}^{2} / \mathbf{s r}\right]$} \\
\hline & & & As & Aw & I-As O & $i-\mathrm{As}$ & As & $\mathrm{Aw}$ & I-As O & $i$-As \\
\hline Tokyo & 1993 & 7,865 & 11.95 & 12.80 & 12.34 & 11.81 & 1.67 & 1.62 & 1.88 & 1.60 \\
\hline \multirow{6}{*}{ Osaka } & 2006 & 20,724 & 10.93 & 10.99 & 10.74 & 10 & 0.98 & 0.86 & 0.94 & 0.69 \\
\hline & 2007 & 21,138 & 11.59 & 11.36 & 11.38 & 10.84 & 1.38 & 1.20 & 1.32 & 1.06 \\
\hline & 2008 & 20,769 & 11.31 & 11.22 & 11.11 & 10.6 & 0.99 & 0.74 & 0.93 & 0.67 \\
\hline & 2009 & 13,844 & 11.04 & 11.16 & 10.99 & 10.55 & 0.97 & 0.70 & 0.92 & 0.67 \\
\hline & 2010 & 17,308 & 39 & 1.32 & 11.36 & 10.69 & 1.5 & 21 & 1.50 & 1.28 \\
\hline & 2011 & 19,041 & 11.75 & 11.36 & 11.57 & 10. & 1.37 & 1.12 & 1.32 & 1.08 \\
\hline \multicolumn{2}{|l|}{$T_{\mathrm{T}}$} & 120,689 & 11.35 & 11.24 & 11.19 & 10.67 & 1.21 & 0.98 & 1.16 & 0.91 \\
\hline
\end{tabular}




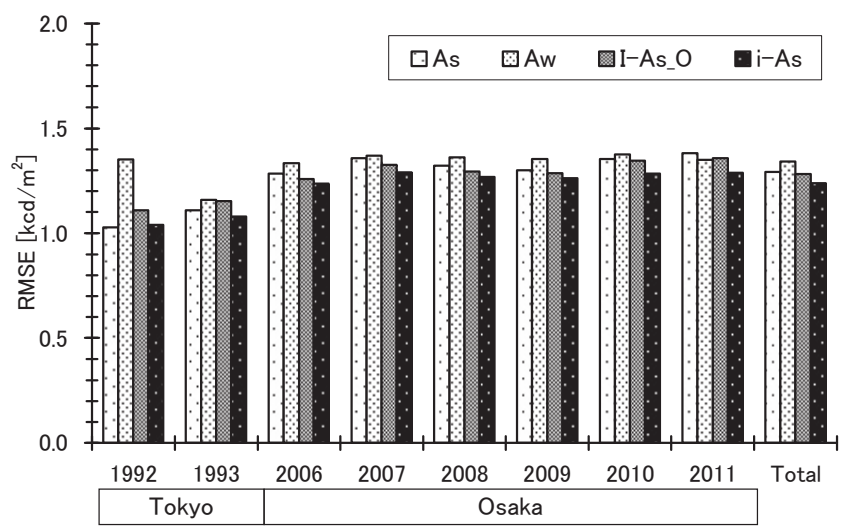

図 2 天空輝度分布の年別 RMSE（東京、大阪）

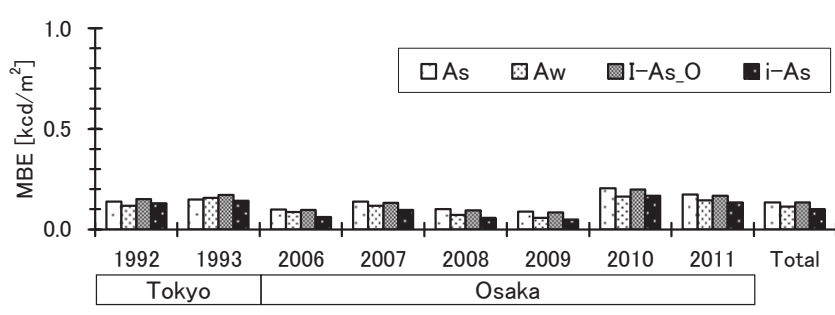

図 3 天空輝度分布の年別 MBE（東京、大阪）

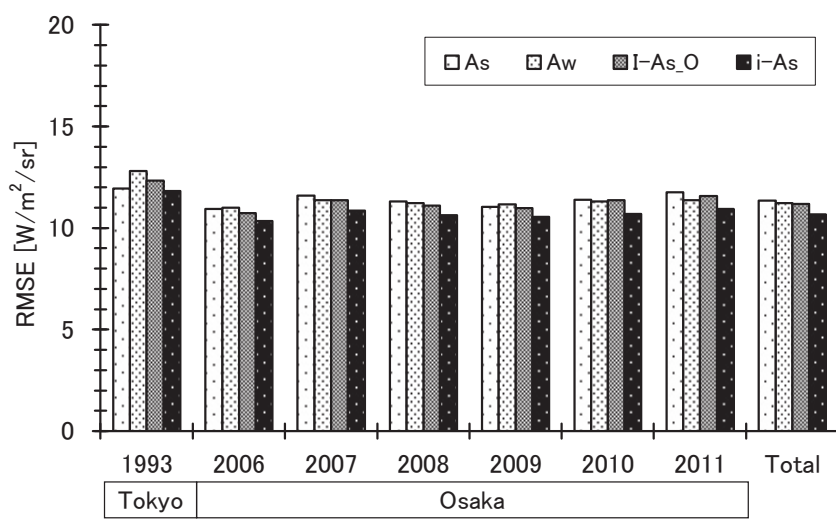

図 4 天空放射輝度分布の年別 RMSE（東京、大阪）

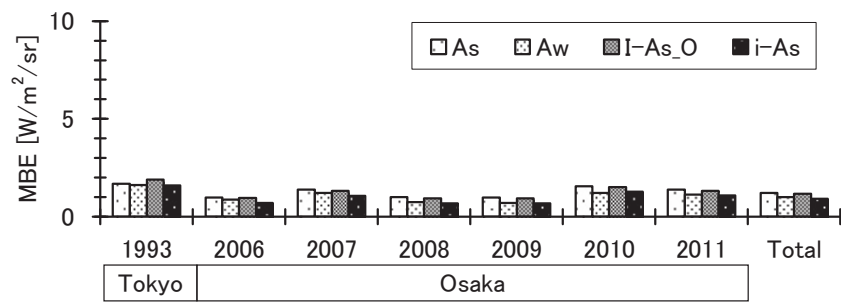

図 5 天空放射輝度分布の年別 MBE（東京、大阪）

\section{2 天空状態別のモデルの比較}

比較対象とした天空モデルによる推定精度について、天空状態別 に比較する。ここで、便宜的に天空状態を、(1)晴天空、(2)中間晴天 空、(3)中間天空、(4)中間皟天空、(5)晴天空の 5 種に分類する。天 空状態は次に示す方法で分類する。先ず、 $K c$ と Cle により天空指標 （Siv）を式（16）のように定義する。次に、 $K c=1 、 C l e=1$ の区域と の位置関係により天空状態を分類する。

$$
S i v=\sqrt{(1.0-K c)^{2}+\left(1.0-C l e^{0.5}\right)^{2}}
$$

(1)晴天空（Clear Sky）：Siv $<0.15$

(2)中間晴天空（Intermediate Clear sky）: $0.15=<$ Siv $<0.3$

(3)中間天空（Intermediate Sky）: $0.3=<$ Siv $<0.9$

(4)中間量天空（Intermediate Overcast Sky）: $0.9=<$ Siv $<1.15$

(5)晴天空（Overcast Sky）: Siv $>=1.15$

分類された天空を $\mathrm{Kc}-\mathrm{Cle}$ 区域に現すと図 6 のようになる。Linke の混濁因子を 2.0 とする晴天空は $K c=1 、 C l e=1$ の区域に相当する。

$K c$ が 1 を超える区域は、雲や大気の状態による影響で天空成分が 増大して全天日射量が晴天空に比べて大きくなる。このとき、直達 成分が低下寸るため Cle が低下している。このような、天空に雲な ぞが散在して全天日射量が晴天空より大きい場合には、その分布は 晴天空から中間天空に近い分布へと変化する。

なお、図 6 の中の空白の区域は、例外的な状況を除き出現機会が ほとんどない区域である。または、天候状態が非常に不安定な状況 や測定に異常がある状況などで発生する可能性のある区域である。

このような区域に相当するデータは対象としない。

以上のような天空分類のもとで、大阪における 2006 年から 2011 年の 6 年間の天空状態別の天空輝度分布と天空放射輝度分布をモデ ル別に推定した結果を表 5 と表 6 に示す。また、天空輝度分布に関 する各モデルによる推定の RMSE と MBE を図 7 と図 8 に、天空放 射輝度分布のそれらを図 9 と図 10 に示す。

モデルと実測值との比較において、天空輝度分布と天空放射輝度 分布はほぼ同様な特性を示している。

5 種の天空状態の中では、雲の動きが激しくて不安定な中間天空 の推定精度が最も低く、4 モデルによる天空輝度と天空放射輝度の

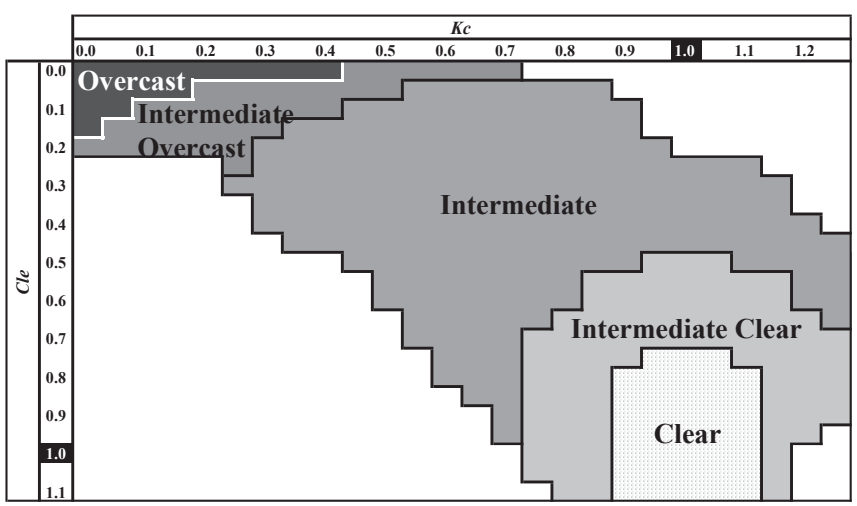

図 $6 \quad K c-C l e$ 区域と便宜的に分類した天空状態

表 5 天空状態別の天空輝度分布の比較（大阪 2006-2011）

\begin{tabular}{|c|c|c|c|c|c|c|c|c|c|}
\hline \multirow{2}{*}{$\begin{array}{c}\text { Sky } \\
\text { conditions }\end{array}$} & \multirow{2}{*}{$\mathbf{N}$} & \multicolumn{4}{|c|}{ RMSE $\left[\mathrm{kcd} / \mathrm{m}^{2}\right]$} & \multicolumn{4}{|c|}{ MBE $\left[\mathbf{k c d} / \mathrm{m}^{2}\right]$} \\
\hline & & As & Aw & I-As_O & $i$-As & As & Aw & I-As_O & $i$-As \\
\hline Overcast & 20,710 & 0.679 & 0.701 & 0.675 & 0.663 & -0.072 & -0.015 & -0.066 & -0.073 \\
\hline I-Overcast & 20,0 & 1.560 & 39 & 27 & 1.507 & 0.000 & 0.025 & -0.042 & -0.088 \\
\hline Intermed & 28,5 & & 1.888 & & 1.7 & 105 & -0 & 093 & 30 \\
\hline I-Clear & 20,0 & 1 & 1457 & 1.294 & 1.286 & 38 & 0.196 & 156 & 0.090 \\
\hline \begin{tabular}{|l} 
Clear \\
\end{tabular} & 23,487 & 1.039 & 1.005 & .076 & 0.992 & 0.461 & 0.367 & 0.468 & 0.359 \\
\hline Total & 112,824 & 1.334 & 1.357 & 1.311 & 1.272 & 0.134 & 0.108 & 0.129 & 0.095 \\
\hline
\end{tabular}

表 6 天空状態別の天空放射輝度分布の比較（大阪 2006-2011）

\begin{tabular}{|c|c|c|c|c|c|c|c|c|c|}
\hline \multirow{2}{*}{\begin{tabular}{|c|}
$\begin{array}{c}\text { Sky } \\
\text { conditions }\end{array}$ \\
\end{tabular}} & \multirow{2}{*}{$\mathbf{N}$} & \multicolumn{4}{|c|}{ RMSE $\left[\mathrm{W} / \mathrm{m}^{2} / \mathrm{sr}\right]$} & \multicolumn{4}{|c|}{ MBE $\left[\mathrm{W} / \mathbf{m}^{2} / \mathbf{s r}\right]$} \\
\hline & & As & Aw & I-As_O & $i-\mathrm{As}$ & As & Aw & I-As_O & $i$-As \\
\hline Overcast & 20,710 & 5.64 & 5.82 & 5.61 & 5.51 & -0.49 & -0.07 & -0.44 & -0.51 \\
\hline \begin{tabular}{|l} 
I-Overcast \\
\end{tabular} & 20,032 & 13.47 & 13.60 & 13.13 & 12.90 & 0.34 & 0.53 & -0.01 & -0.39 \\
\hline Intermediate & 28,590 & 6.13 & 16.17 & 5.87 & 15.3 & 0.89 & -0.17 & 0.78 & 1.09 \\
\hline I-Clear & 20,0 & 1.59 & 1 & 11.01 & 10.39 & 1.27 & 1.68 & 1.39 & 0.90 \\
\hline \begin{tabular}{|l|} 
Clear \\
\end{tabular} & 23,487 & 8.54 & 7.93 & 8.91 & 7.85 & 3.79 & 3.10 & 3.83 & 3.05 \\
\hline Total & 112,824 & 11.35 & 11.24 & 11.19 & 10.67 & 1.21 & 0.98 & 1.16 & 0.91 \\
\hline
\end{tabular}




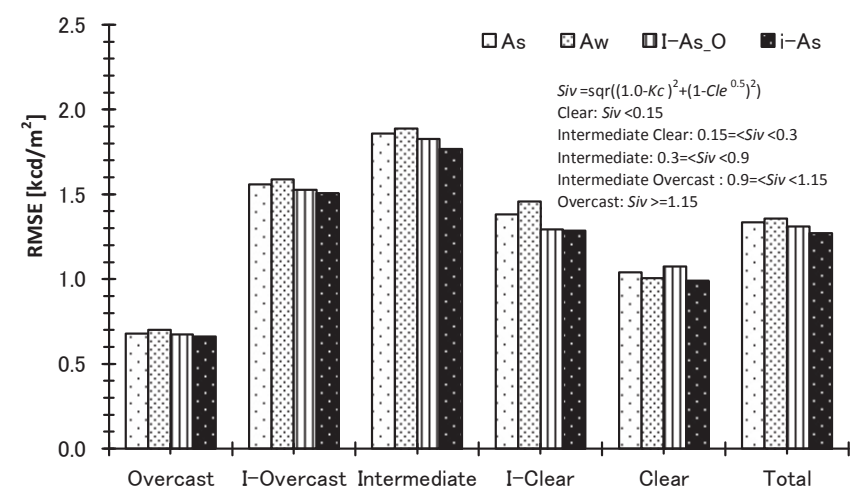

図 7 天空状態別の天空輝度分布の RMSE の比較

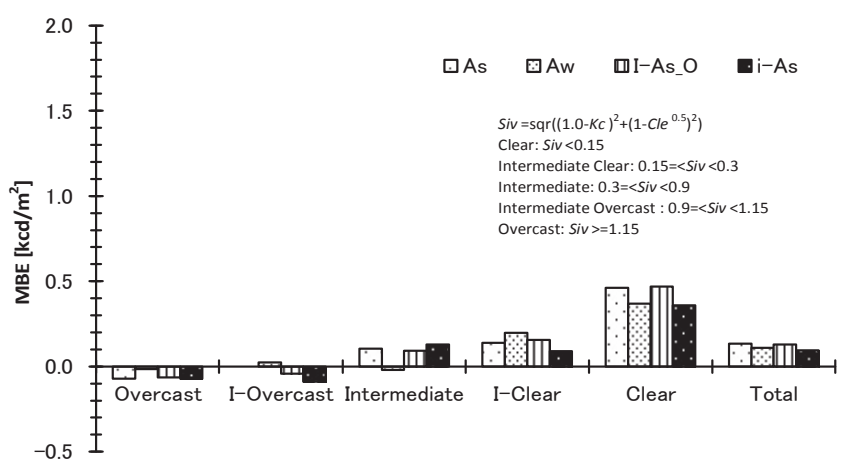

図 8 天空状態別の天空輝度分布の MBE の比較

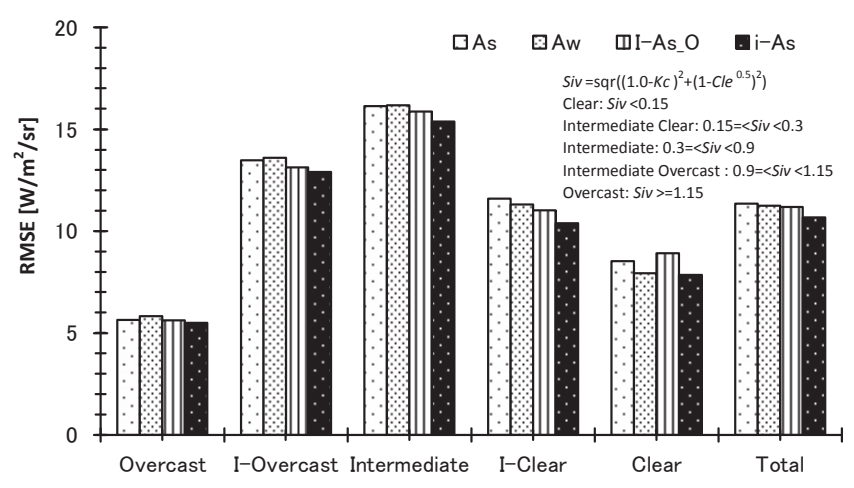

図 9 天空状態別の天空放射輝度分布の RMSE の比較

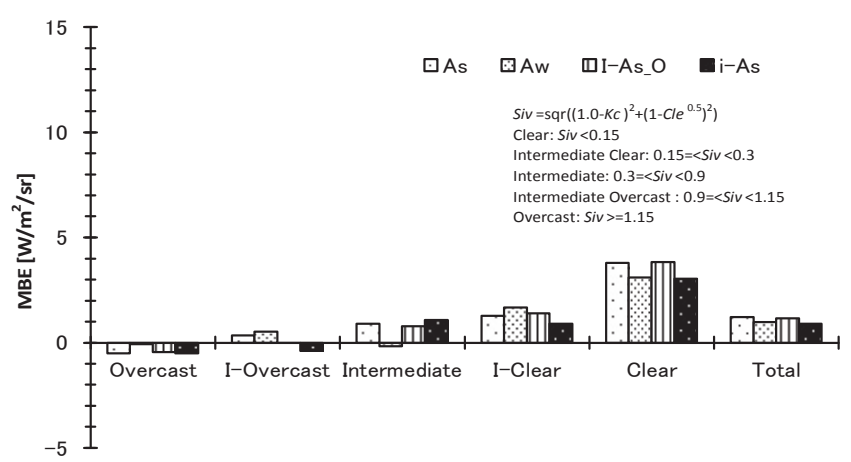

図 10 天空状態別の天空放射輝度分布の MBE の比較

改良された $i$-As の推定精度が最も高い。

晴天空ならびにほぼ晴天空は、他の天空状態に比べて相対分布の 天空位置依存性が大きいことや太陽付近の測定困難部分の影響など のため、MBE は他の天空に比べて大きくなっている。この場合でも、 輝度と放射輝度の MBE の絶対值が $0.5 \mathrm{kcd} / \mathrm{m}^{2}$ 未満、 $4 \mathrm{~W} / \mathrm{m}^{2} / \mathrm{sr}$ 未満 と小さく、実用的に十分な推定精度を有していると考える。

なお、Aw は晴天空についてはかなり良好な推定が可能であるが 晴天空以外の天空状態では他のモデルが優れている。

いずれにしても、天空輝度分布と天空放射輝度分布の双方におい て、すべての天空状態で $i$-As の推定精度が最も優れている。

図 11 と図 12 には、天空輝度分布と天空放射輝度分布の天空状態 別の、As とAw と $i$-As による推定值の RMSE の出現頻度を示す。

これらの図においては、ピークが縦軸に近くかつ急峻になってい るほど推定精度が高いことを表す。図中では出現頻度が似通ってい るためモデルの判別が困難な部分があるが、どのモデルの RMSE の デルに比べて最も小さい。すなわち、現状のモデルと比較して整備
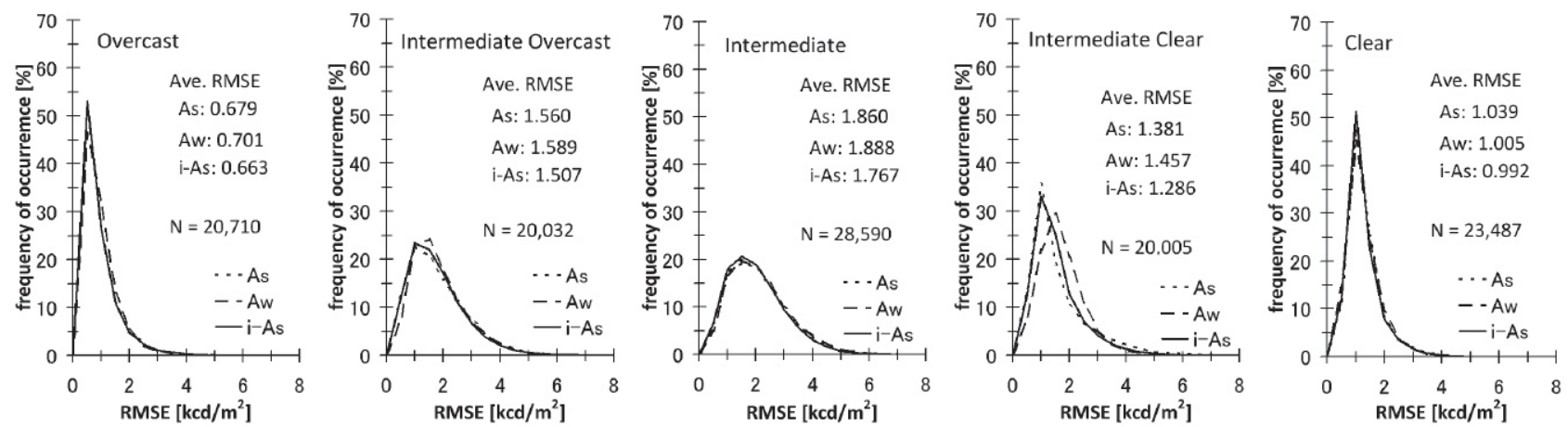

図 11 天空状態別の天空輝度分布の RMSE の出現頻度 

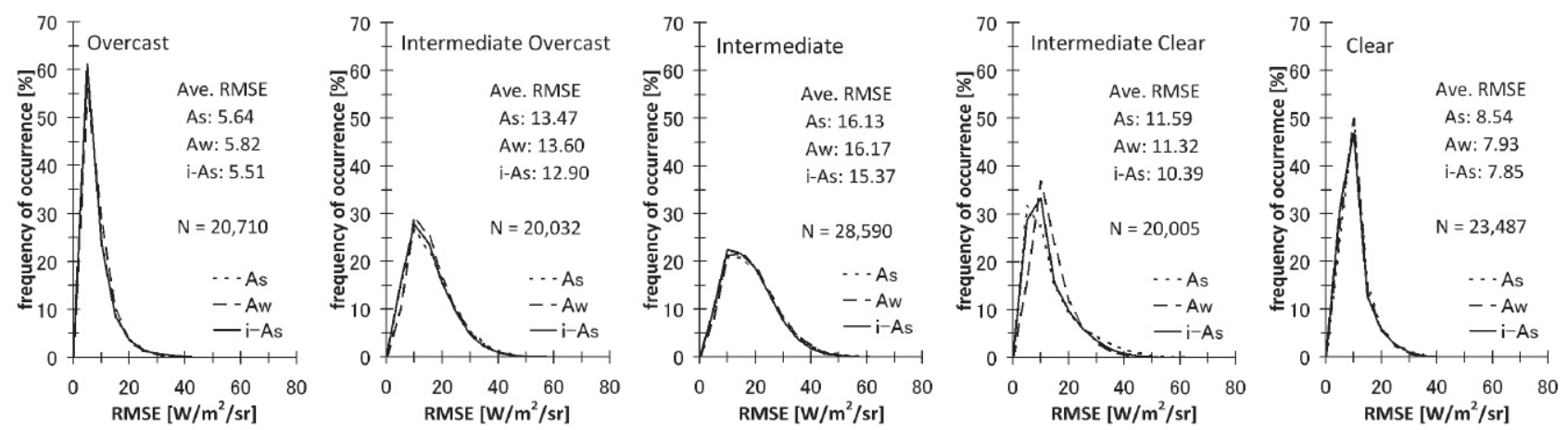

図 12 天空状態別の天空放射輝度分布の RMSE の出現頻度

出現頻度も、量天空と晴天空では同様な特性を示している。中間天 空は各モデルのピーク值が小さく、RMSE がやや広範囲に分布し、 不安定な天空状態であることを示している。

各天空状態において、 $i$-As は RMSEの分布が最も安定して小さく、 高精度な推定が可能であることを示している。

\section{3 モデル別の天空位置別の推定精度}

天空要素の位置を便宜的に次の 4 部位に分類して、各部位の天空 要素の推定精度について比較する。なお、太陽からの各距離 $18^{\circ}$ 未 満と天空要素の高度が $6 \circ$ のデータは対象としない。

(1) 天空要素の高度 $60^{\circ}$ 以上の天空要素(Zenith)。

（2）（1)を除き、太陽方位軸に対して天空要素の方位角が $445^{\circ}$ の 空要素(South)。

（3）(1)を除き、太陽方位軸に対して天空要素の方位角が $+135^{\circ}$ 以上、 -135以下の天空要素(North)。

（4）（1)を除き、太陽方位軸に対して天空要素の方位角が-45〜 $-135^{\circ}$ と $45^{\circ} \sim 135^{\circ}$ の天空要素(East \& West)。

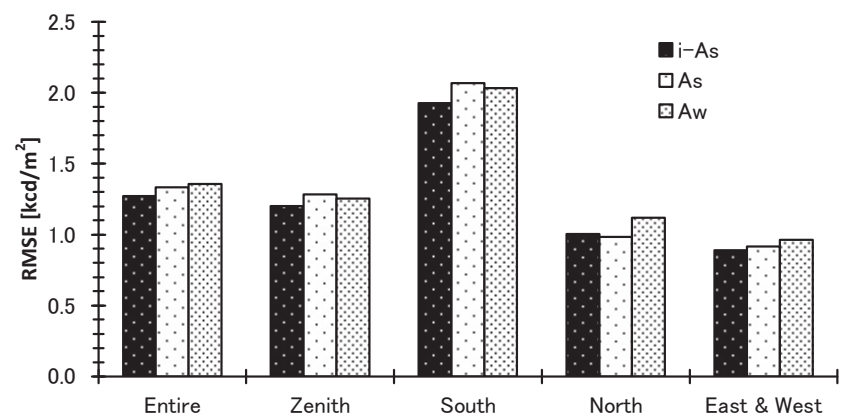

図 13 天空輝度の天空要素の位置別推定值の RMSE の比較

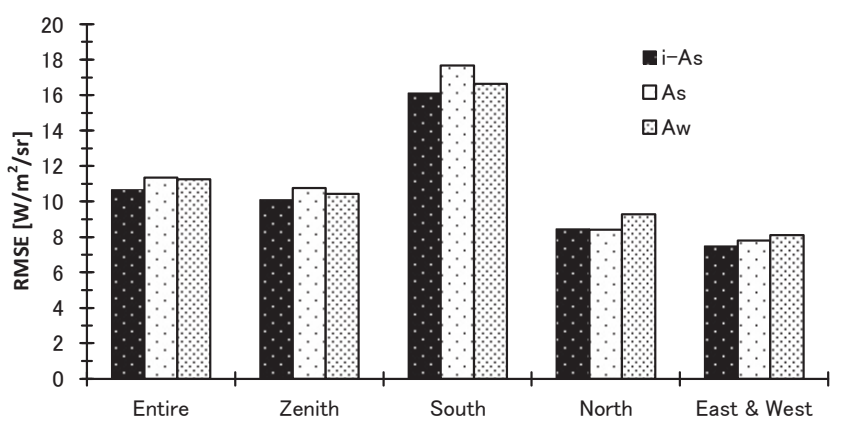

図 14 天空放射輝度の天空要素の位置別推定值の比較
すべての天空状態における天空輝度分布に関する天空要素の位置 別推定值の RMSE を図 13 に、天空放射輝度分布に関する天空要素 の位置別推定值の RMSE を図 14 に示す。

天空輝度分布は太陽に直面する South の RMSE が他の方角に比心゙ て大きい傾向があり、Zenith がこれに続く。これらの太陽位置に近 い天空要素が含まれる位置の測定では、直射日光の影響により信頼 性の高いデータを取得することが困難であり、その影響が現れてい るものと考えられる。このような中で、全般的に $i$-As の RMSE が小 さく、推定精度が高いことを示している。

天空放射輝度分布に関する推定值の天空要素の位置別比較は、天 空輝度と同様な特性を示している。この場合も、 $i$-As の RMSE はど の天空位置においても最も小さく、良好な推定が可能であることを 示している。

\section{4 モデル別の鉛直面日射量の推定}

モデル別の天空分布を基にした鉛直面照度・日射量の推定值につ いて、2006 年〜2011 年の実測值と比較する。ここでは、i-As、As、 Aw に加えて一様天空（Is）を比較の対象とする。

鉛直面照度の推定值の RMSE と MBE の 6 年間の平均值を図 15 、 16 に示す。

鉛直面照度の RMSE は、全体的に $i$-As が最も小さく、Aw、As の 順に大きくなっているが、3 者において極端な相違はみられない。 Is は、RMSE が分布型の 3 モデルに比べて極端に大きい。Is は直射 日光が当たる面は小さく推定し、直射日光が当たらない面は大きく 推定する傾向がある。したがって、例えば東面の MBE は、午前中 は負になり、午後は正になる。このため、MBE を単純平均すると、 その日の天候状態によっては午前と午後の正負が相殺されて一日の 平均 MBE はかなり小さな值となることもある。現実には、時間帯 別に大きな乘離が見られる。西面も東面と時間帯が逆になるが、同 様な傾向を示す。したがって、とくに東面と西面の平均 MBE は必 ずしも現象を十分に説明していないことに留意する必要がある。

鈆直面日射量の推定值の RMSE と MBE の 6 年間の平均值を図 17 と図 18 に示す。

鉛直面日射量の RMSE は、鉛直面照度と非常に良く似た特性を示 しており、分布型の 3 モデルにおいて極端な相違はみられないが、 す心゙ての方位で $i$-As が最も小さく、As、Aw の順に大きくなってい る。鉛直面照度と同様に、MBE も Is 以外のモデルにおいては極端 な相違は見られない。 


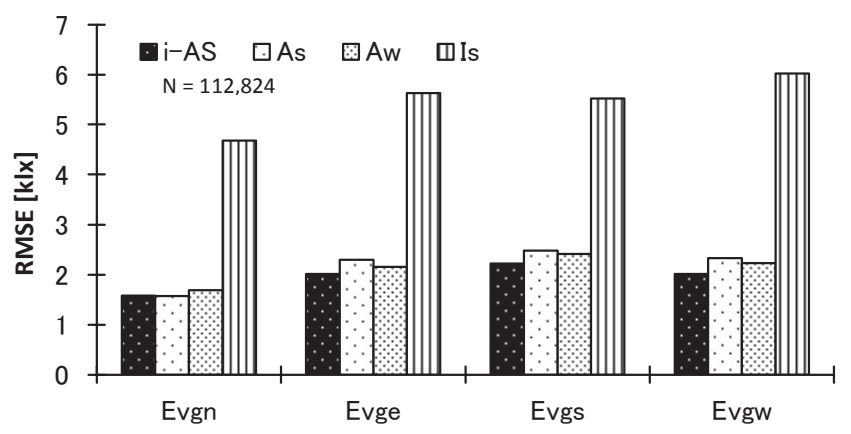

図 15 鈆直面照度の推定值の RMSE

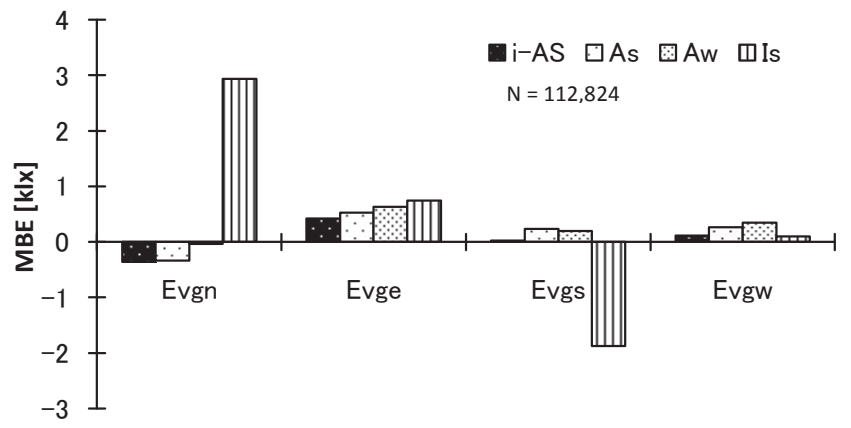

図 16 鉛直面照度の推定值の $\mathrm{MBE}$

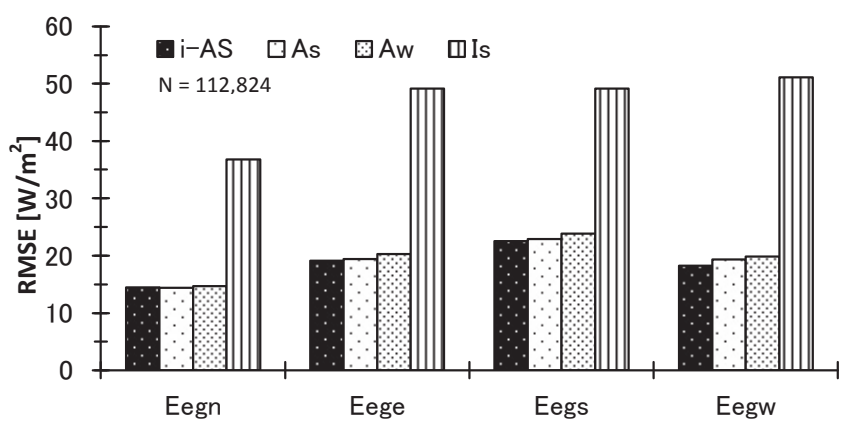

図 17 鋁直面日射量の推定值の RMSE

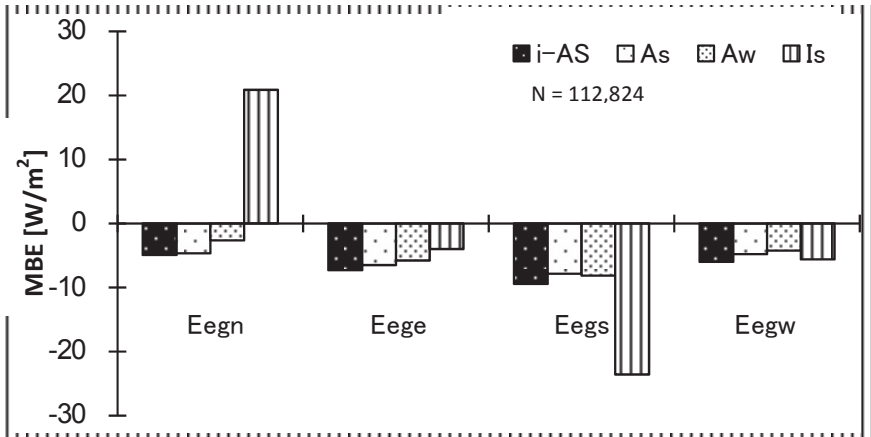

図 18 鈆直面日射量の推定值の $\mathrm{MBE}$

鉛直面日射量を一様天空で想定すると、直達日射が当たる時、当 該面の鈆直面日射量を小さく予測する傾向があるため、例えば、冷 房のピーク負荷を過小に評価することになり、機器の能力不足など に十分に注意する必要があることを示している。このような状況か ら、一様天空を基にした鉛直面の照度や日射量を、現実の建築環境・ 設備の計画・設計・計算・予測に適用することは不適切といえる。

分布型モデルによる鉛直面照度と鉛直面日射量の方位別の推定值 の傾向として、北面の RMSEが最も小さく、次に東面と西面の RMSE と続き、南面の RMSE が最も大きい傾向にある。これは、スカイス
キャナーで測定する場合に、太陽位置と太陽周辺の天空の輝度・放 射輝度の測定に不確かな部分があり、これらの影響度合いの大きい 方位の測定精度が低いため、これに伴って推定精度も低下寸る。

6 まとめ

既報 ${ }^{1}$ において、大阪における IDMP の測定データを基に、既提 案の All Sky Model（As）を改良したモデル（I-As_O）を提案した。 今回、さらに検討を重ねて All Sky Model を整備した。整備されたモ デル（i-As: improved All Sky Model）は、東京（1992 年一1993 年） と大阪（2006 年一2011 年）の実測データを基に比較検討された。

天空の分布測定は市販の測定器に依存し、この中でいくつかの測 定上の課題注 3) も浮き彫りにされ、モデル化における不都合も感じ られた。その中で、今回提案するモデルは、現状の測定器を基にし た限界モデルとも考えられる。

通年の推定值や、天空状態別、天空位置別の推定值や、鉛直面照 度・日射量の推定值などの比較において、本研究で比較対象とした As、Aw は、いずれもかなり高精度で実用的な完成度の高いモデル であることが明らかになった。さらに、整備された $i$-As は、いずれ の条件でも推定精度が最も高いことが確認され、変移する現象をよ り現実的に再現することが可能となった。既に既報のモデルを参照 されていた方は、本論文の係数に修正いただければ幸いである。

\section{謝辞}

本研究の一部は、科研費基盤研究(B) 17360285、(B)21360279 (代 表 : 井川憲男)の援助を受けた。記して謝意を表する。

注

注1) International Daylighting Measurement Programme の略。CIE が昼光と日射 の基䃈データ取得と標準資料作成のため、1991 年から世界各地で長期測 定老実施。

注2）太陽に近接する天空要素は、直射の影響で正確な測定が不可能である。 この部分の輝度と放射輝度は $50 \mathrm{kcd} / \mathrm{m}^{2} 、 420 \mathrm{~W} / \mathrm{m}^{2} / \mathrm{sr}$ と仮置きする。

注3）天空の雲の増減やその移動、太陽位置の移動などを考慮すると、可能な 限り短時間で分布測定が完了寸ることが望まれる。また、センサーはシ ヤープなカットオフ開口角を有していることが必須である。

\section{参考文献}

1）井川憲男，永村一雄：天空輝度・放射輝度分布を推定する All Sky Model の改良, 日本建築学会環境系論文集, No.673, pp. 121-127, 2012.3.

2) Igawa, N., Koga, Y., Matsuzawa, T., Nakamura, H.: Models of Sky Radiance Distribution and Sky Luminance Distribution, Solar Energy, Vol. 77, No. 2, pp. 137-157, 2004.

3) CIE: Spatial Distribution of Daylight - CIE Standard General Sky, CIE S 011/E:2003, 2003

4) Perez, R., Seals, R., and Michalsky, J.: All-weather model for sky luminance distribution - Preliminary configuration and validation, Solar Energy, Vol. 50, No 3, pp. 235-245, 1993.

5) 細淵勇人, 吉田治典, 上谷芳昭: 日射量を用いた CIE 標準一般天空の天空 タイプ推定手法に関する研究, 日本建築学会環境系論文集, No. 609, pp. 31-38, 2006.11

6) CIE: Guide to recommended practice of daylight measurement, Pub. CIE 108 , ISBN 390073450 X, 1994.

7) 井川憲男: 昼光と日射の研究クラスの測定システム, 日本建築学会大会学 術講演梗概集 D1, pp. 255-256, 1992.

8) Kasten, F. and Young, A.T.: Revised optical air mass tables and approximation formula, Applied Optics 28 (22), pp. 4735-4738, 1989.

（2012年10月10日原稿受理，2013年 1 月25日採用決定） 